\title{
ANALISIS TINGKAT KEBISINGAN AKIBAT ARUS LALU LINTAS DI PEMUKIMAN KOTA PONTIANAK (STUDI KASUS : PEMUKIMAN SUNGAI RAYA DALAM KECAMATAN PONTIANAK TENGGARA)
}

Ferdyana Annisaa Alsey, Dian Rahayu Jati, Kiki Prio Utomo

Program Studi Teknik Lingkungan Jurusan Teknik Sipil Fakultas Teknik Universitas Tanjungpura, Pontianak Email : ferdyanaannisaalsey@gmail.com

\begin{abstract}
ABSTRAK
Kebisingan adalah suara yang tidak dikehendaki oleh manusia dan merupakan faktor lingkungan yang dapat berpengaruh negatif terhadap kesehatan manusia dalam tingkat dan jangka waktu tertentu. Tujuan penelitian ini adalah untuk mengetahui tingkat kebisingan akibat arus lalu lintas di kawasan pemukiman dan untuk mengetahui tingkat ketergangguan masyarakat terhadap kebisingan jalan pada pemukiman Jl. Sungai Raya Dalam Kecamatan Pontianak Tenggara. Hasil penelitian menunjukkan tingkat kebisingan di pemukiman Jl. Sungai Raya Dalam Kecamatan Pontianak Tenggara memiliki nilai tertinggi pada titik satu, yaitu pada Komplek Villa Lestari sebesar $68,8 \mathrm{~dB}$ pada hari kerja dan $65,8 \mathrm{~dB}$ pada hari libur dengan waktu pengukuran $06.00-08.00$ WIB dan 15.00 - 17.00 WIB. Tingkat ketergangguan yang didapat dengan menggunakan perhitungan skala Likert memiliki hasil 51\% dengan tingkat ketergangguan sedang terganggu. Nilai korelasi yang dihasilkan dengan menggambarkan hubungan tingkat kebisingan dan tingkat ketergangguan masyarakat dengan alat bantu SPSS ver 16.0 adalah 0,14 pada hari kerja di kebisingan pagi hari dan 0,07 pada hari libur di kebisingan sore hari. Nilai korelasi tersebut termasuk korelasi lemah. Tingkat kebisingan di pemukiman Jl. Sungai Raya Dalam Kecamatan Pontianak Tenggara telah melebihi batas ambang baku mutu menurut Keputusan Menteri Lingkungan Hidup No. 48 tahun 1996 yang hanya diperbolehkan $55 \mathrm{~dB}$ untuk kawasan pemukiman sehingga dapat diberikan upaya pengendalian. Upaya pengendalian yang dapat direkomendasikan adalah penanggulangan langsung di sumbernya dengan penambahan rambu jalan, membuat barrier dalam bentuk pagar dan dinding tinggi, penggunaan jalur hijau dengan menanam pohon di sekitar area pemukiman sehingga dapat mengurangi tingkat kebisingan pada daerah pemukiman.
\end{abstract}

Kata Kunci : Kebisingan, Arus Lalu Lintas, Pemukiman Kota Pontianak

\begin{abstract}
Noise is unwanted sound by the human and environmental factors that may adversely affect human health and the level of a certain period. The purpose of this study was to determine the level of noise due to the flow of traffic in residential areas and to determine the level of public investments against road noise on residential JI. Sungai Raya In the District of South East Pontianak. The results showed noise levels in residential Jl. Sungai Raya In the District of Pontianak Southeast has the highest value at a single point, namely Komplek Villa Lestari of $68.8 \mathrm{~dB}$ and $65.8 \mathrm{~dB}$ weekdays on holiday with the measurement time 06:00 to 08:00 pm and 15:00 to 17:00 pm. investments level obtained by using Likert scale calculations have results investments $51 \%$ to the level of being disrupted. The correlation value is generated by describing the correlation between the noise and the level of the community with tools investments SPSS version 16.0 was 0.14 on a weekday in the morning noise and 0.07 on holidays in the noise of the afternoon. The correlation values including the correlation is weak. The noise level in residential JI. Sungai Raya In the District of South East Pontianak has exceeded the threshold quality standards according to the Decree of the Minister of Environment No. 48 of 1996 that only allowed $55 \mathrm{~dB}$ for residential areas so that it can be given control efforts. Control measures that can be recommended is a direct response at the source with the addition of road signs, make a barrier in the form of fences and high walls, the use of the green belt by planting trees around the residential areas so as to reduce noise levels in residential areas.
\end{abstract}

Keywords : Noise, Traffic Flow, Pontianak City 


\section{PENDAHULUAN}

Kebisingan adalah suara yang tidak dikehendaki oleh manusia dan merupakan faktor lingkungan yang dapat berpengaruh negatif terhadap kesehatan manusia dalam tingkat dan jangka waktu tertentu. Secara umum kebisingan di daerah perkotaan dihasilkan melalui sumber berbeda, di antaranya kontruksi dan kegiatan komersial, industri, bandara dan lalu lintas. Menteri Negara Lingkungan Hidup No: Kep. Men-48/MEN.LH/11/96 menyatakan tingkat baku mutu kebisingan khusus untuk pemukiman adalah sebesar $55 \mathrm{~dB}(\mathrm{~A})$.

Kota Pontianak merupakan ibu kota Provinsi Kalimantan Barat yang memiliki jumlah penduduk sebanyak 598.097 jiwa (BPS Provinsi Kalimantan Barat, 2015) yang dapat dilihat sering terjadinya kemacetan pada setiap jam-jam sibuk dengan volume kendaraan bermotor yang terus meningkat tanpa terkendali. Sementara banyak jalan raya telah mencapai tingkat jenuh (v/c) melebihi kapasitas atau melebihi 0,7 derajat kejenuhan (Dinas Perhubungan, 2011). Padatnya aktivitas penduduk Kota Pontianak pada saat ini menyebabkan meningkatnya jumlah kendaraan bermotor di jalan raya sehingga aktivitas lalu lintas semakin padat. Tingkat pertumbuhan kepemilikan kendaraan bermotor untuk Kota Pontianak mencapai 729.979 unit dibandingkan dengan tahun 2010 yang hanya mencapai 574.322 unit (Dispenda, 2011). Hal ini menunjukan terjadinya pertumbuhan kendaraan yang tidak sebanding dengan pertambahan prasarana seperti angkutan umum sehingga masyarakat lebih memilih menggunakan kendaraan pribadi guna memenuhi kebutuhan sehari-hari dan menyebabkan volume kendaraan bermotor di jalan lebih banyak dari sebelumnya dan menimbulkan kebisingan akibat bunyi kendaraan bermotor tersebut.

Pemukiman di Kota Pontianak berpotensi mengalami polusi suara karena berada tepat disamping jalan raya. Salah satunya yang berpotensi mengalami polusi suara akibat padatnya arus lalu lintas adalah pemukiman di Jl. Sungai Raya Dalam, Kecamatan Pontianak Tenggara. Jalan tersebut merupakan jalan yang berhadapan dengan Kabupaten Kuburaya yang hanya dibatasi oleh parit kecil. JI. Sungai Raya Dalam tengah mengalami pelebaran, sehingga jarak pemukiman lebih dekat dengan jarak 1-10 m dari perkerasan jalan raya sehingga menyebabkan pemukiman sudah termasuk dalam zona bising (Pedoman Teknik, 1999). Penelitian kebisingan ini menghubungkan antara tingkat kebisingan di pemukiman Jl. Sungai Raya Dalam Kecamatan Pontianak Tenggara dengan tingkat ketergangguan masyarakat akibat arus lalu lintas yang akan dianalisis menggunakan alat bantu SPSS ver 16.0 guna untuk melihat nilai korelasi.

\section{METODOLOGI PENELITIAN}

\section{A. LOKASI DAN WAKTU PENELITIAN}

Penelitian dilaksanakan disepanjang pemukiman Jl. Sungai Raya Dalam Kecamatan Pontianak Tenggara yang dapat dilihat pada gambar 1 :

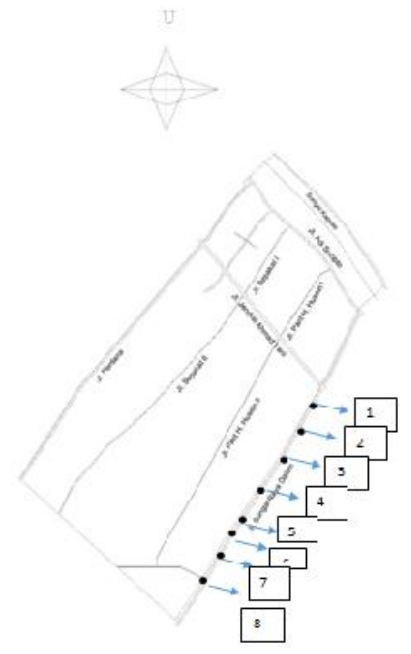

Gambar 1 Lokasi Penelitian 
Waktu penelitian dilakukan pada hari Senin dan Minggu mewakili hari kerja dan hari libur. Pengukuran dilakukan pada pukul 06.00-08.00, 11.00-13.00 dan 15.00-17.00 WIB sesuai cara pengukuran Dinas Perhubungan dengan mengukur jumlah kendaraan yang melintas sesuai jenisnya dengan waktu satu jam.

\section{B. ALAT}

Alat-alat yang digunakan dalam penelitian ini adalah Sound Level Meter, Stopwatch, Counting Meter, kamera, pita ukur dan alat tulis.

\section{PROSEDUR PENELITIAN}

Berikut adalah prosedur yang dilakukan dalam penelitian ini:

\section{- Pengambilan Data}

1. Data kebisingan : pengukuran kebisingan dilakukan di depan komplek perumahan pada jarak 0 $\mathrm{km}$, masuk ke dalam komplek pada jarak 0,2 km dan pada titik terakhir dibelakang komplek pada jarak 0,5 km menggunakan alat Sound Level Meter.

2. Kendaraan : pengukuran jumlah kendaraan yang melintas dilakukan selama satu jam pengukuran, yakni pada pukul 06.00-07.00, 07.00-08.00, 11.00-12.00, 12.00-13.00, 15.00$16.00,16.00-17.00$ wib.

3. Kuesioner : penyebaran kuesioner dilakukan dengan mengambil 120 responden yang terpapar kebisingan. Menurut Roscoe (1975) yang dikutip Sakran (2006) menyatakan bahwa penelitian korelasional jumlah sampel untuk menghasilkan hasil yang baik adalah 30-500 sampel. Penyebaran kuesioner dilakukan untuk mengetahui tingkat ketergangguan masyarakat terhadap kebisingan di Jl. Sungai Raya Dalam Kecamatan Pontianak Tenggara.

\section{ANALISIS DATA}

Penelitian berjenis kuantitatif dengan penyajian data menggunakan analisis deskriptif yang dibantu dengan alat program Excel agar lebih mudah dipahami dan lebih intesif, maka data hasil survei dan pengukuran akan disajikan dalam bentuk tabel, grafik dan diagram. Penyajian data menggunakan program Excel untuk membandingkan hasil tingkat kebisingan terhadap tingkat ketergangguan terhadap penduduk di pemukiman jl. Sungai Raya Dalam bagian Kecamatan Pontianak Tenggara. Pengelolaan hasil kuesioner menggunakan Skala Likert guna untuk melihat hasil tingkat ketergangguan masyarakat akibat kebisingan arus lalu lintas. Analisis hubungan tingkat kebisingan dan tingkat ketergangguan menggunakan metode korelasi dengan bantuan aplikasi SPSS vers 16.0.

\section{HASIL DAN PEMBAHASAN}

A. Tingkat Kebisingan

Pengukuran tingkat kebisingan dilakukan di pemukiman sepanjang Jl. Sungai Raya di daerah pemukiman bagian Kecamatan Pontianak Tenggara dengan menggunakan alat ukur Sound Level Meter (SLM). Jl. Sungai Raya Dalam memiliki panjang 4,2 km dan pada pengukuran ini dilakukan setiap jarak $0,5 \mathrm{~km}$ sehingga didapatlah 8 titik pengambilan sampel. Pada penelitian juga dilakukan pengukuran aktivitas lalu lintas yang mencerminkan pola lalu lintas perkotaan.

Peningkatan jumlah kendaraan terjadi pada pagi dan sore hari, ketika jam masuk dan keluar kantor pada hari kerja. Jumlah kendaraan hanya di pantau pada jam-jam tertentu yang mengikuti perhitungan Dinas Perhubungan yang menyatakan bahwa jam-jam padat lalu lintas Kota Pontianak terletak pada pukul 06.00-08.00, 11.00-13.00 dan 15.00-17.00. Jumlah kendaraan yang melintas masuk dan keluar di setiap perumahan pada 8 titik dibandingkan dengan tingkat kebisingan pada jam yang sama di hari libur dan kerja dapat dilihat pada gambar 2 dan 3. 

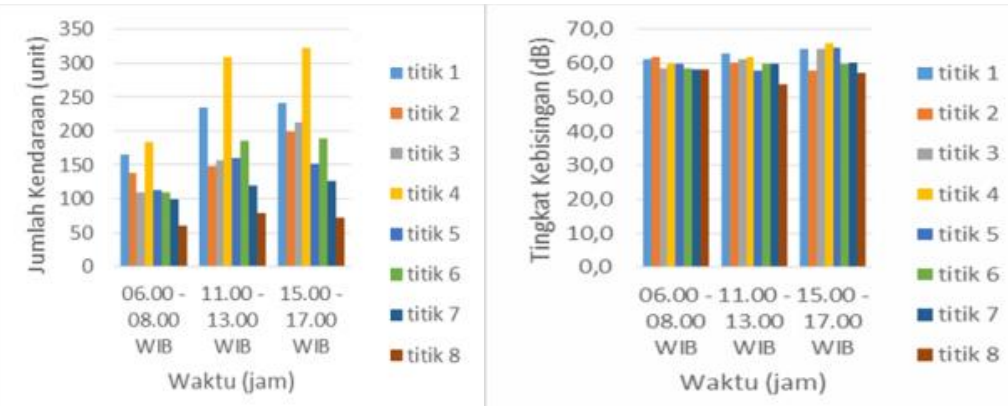

\section{Gambar 2 Hasil Pengukuran Jumlah Kendaraan dan Kebisingan Pada Hari Libur}

Dari gambar 2 merupakan grafik perbandingan tingkat kebisingan dan jumlah kendaraan yang melintas di JI. Sungai Raya Dalam pada hari libur, dengan tiga waktu pengukuran, yakni pukul 06.0008.00 WIB dan 15.00-17.00 WIB. Triwinarti (2015) menyatakan dalam penelitiannya bahwa jumlah kendaraan mengakibatkan adanya peningkatan intensitas bunyi. Pada grafik tersebut untuk semua titik dapat disimpulkan bahwa semakin meningkat jumlah kendaraan yang melintas maka semakin tinggi pula tingkat kebisingan untuk titik-titik tersebut. Namun, ada beberapa titik pada pengukuran tertentu mengalami penurunan tingkat kebisingan tetapi jumlah kendaraan meningkat, ini dapat dilihat pada titik 2. Hal ini dikarenakan pada waktu pengukuran tersebut kendaraan banyak melintas tetapi pengendara mengurangi laju kecepatan sehingga tingkat kebisingan mengalami penurunan. Pengendara mengurangi kecepatan karena adanya pengerjaan jalan yang sedang dalam pelebaran. Didukung dengan penelitian Ansusanto (2006) menyatakan penurunan kecepatan lalu lintas hingga $20 \mathrm{~km} / \mathrm{jam}$ akan menurunkan tingkat kebisingan.
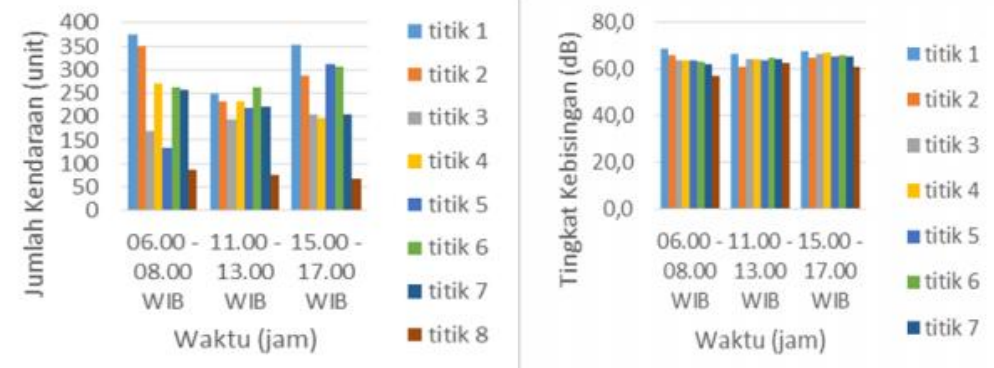

\section{Gambar 3 Hasil Pengukuran Jumlah Kendaraan dan Tingkat Kebisingan Pada Hari kerja}

Dari gambar 3 merupakan perbandingan tingkat kebisingan dan jumlah kendaraan yang melintas di Jl. Sungai Raya Dalam pada hari kerja di 8 titik pengambilan sampel pada waktu pengukuran yang sama, yakni pada pukul $06.00-08.00,11.00-13.00$ dan $15.00-17.00$ WIB. Tingkat kebisingan dan jumlah kendaraan berbanding lurus dan meningkat dibandingkan hari libur. Hal ini dikarenakan banyaknya aktifitas yang dilakukan penduduk pada jam-jam pengukuran tersebut. Bangun (2009) menyatakan bahwa volume kendaraan dihari kerja pada jam tersebut cenderung lebih banyak. Kondisi Jl. Sungai Raya Dalam merupakan kawasan pendidikan dan perkantoran. Terdapat beberapa tempat pendidikan di daerah Sungai Raya Dalam, yakni STIKES Muhammadyah Pontianak, AKBID Panca Bhakti, SMA/SMK AL-Madani, SD Negeri 26 Pontianak dan MTS sehingga pada pagi dan sore hari jalan-jalan tersebut untuk hari kerja selalu ramai lalu lintas. Untuk melihat kendaraan yang melintas di Jl. Sungai Raya Dalam pada hari kerja dan libur dengan jenisnya dapat dilihat pada tabel 1 dan 2. 
Tabel 1 Kendaraan Yang Melintas di Hari Libur

\begin{tabular}{|c|c|c|c|c|c|c|c|c|c|}
\hline \multirow[t]{2}{*}{ No. } & \multirow[t]{2}{*}{ Waktu (WIB) } & \multicolumn{8}{|c|}{ Sepeda Motor (Unit) } \\
\hline & & Titik 1 & Titik 2 & Titik 3 & Titik 4 & Titik 5 & Titik 6 & Titik 7 & Titik 8 \\
\hline 1 & $06.00-07.00$ & 71 & 60 & 45 & 79 & 49 & 55 & 47 & 30 \\
\hline 2 & $07.00-08.00$ & 81 & 59 & 52 & 90 & 55 & 48 & 49 & 28 \\
\hline 3 & $11.00-12.00$ & 110 & 47 & 54 & 156 & 70 & 98 & 54 & 36 \\
\hline 4 & $12.00-13.00$ & 105 & 60 & 61 & 130 & 75 & 71 & 59 & 39 \\
\hline 5 & $15.00-16.00$ & 106 & 84 & 84 & 132 & 74 & 87 & 63 & 38 \\
\hline \multirow[t]{2}{*}{6} & $16.00-17.00$ & 116 & 89 & 85 & 164 & 63 & 90 & 55 & 29 \\
\hline & Total & 589 & 399 & 381 & 751 & 386 & 449 & 327 & 200 \\
\hline No. & Waktu (WIB) & \multicolumn{8}{|c|}{ Mobil (Unit) } \\
\hline 1 & $06.00-07.00$ & 4 & 5 & 5 & 2 & 5 & 4 & 2 & 1 \\
\hline 2 & $07.00-08.00$ & 9 & 8 & 4 & 5 & 4 & 4 & 2 & 1 \\
\hline 3 & $11.00-12.00$ & 5 & 14 & 15 & 13 & 7 & 6 & 2 & 2 \\
\hline 4 & $12.00-13.00$ & 15 & 14 & 17 & 12 & 8 & 5 & 4 & 2 \\
\hline 5 & $15.00-16.00$ & 13 & 10 & 15 & 12 & 7 & 5 & 4 & 2 \\
\hline 6 & $16.00-17.00$ & 7 & 14 & 18 & 15 & 8 & 6 & 5 & 2 \\
\hline & Total & 53 & 65 & 74 & 59 & 39 & 30 & 19 & 10 \\
\hline
\end{tabular}

\section{Sumber: Hasil Analisis, 2016}

Pada tabel 1 dapat dilihat banyaknya kendaraan bermotor yang melintas pada titik 1, 2, 3, 4, 5, 6, 7 dan 8. Pengukuran dilakukan dengan mengukur jenis sepeda motor dan mobil. Pada tabel 4.1 merupakan perbandingan jumlah kendaraan yang melintas dalam waktu bersamaan pada kedelapan titik pengambilan sampel. Untuk jenis sepeda motor yang melintas pada 8 titik untuk beberapa waktu tinggi sepeda motor dan mobil yang melintas berada ada titik 1 dan 4 selama tiga waktu pengukuran. Hal ini dikarenakan pada titik tersebut untuk kondisi eksisting terdapat beberapa tempat seperti pasar, swalayan, kafe dan rumah makan. Sehingga pada jam-jam tersebut kepadatan lalu lintas meningkat dibandingkan dengan titik-titik yang lain. Sedangkan untuk melihat jumlah kendaraan yang melintas pada hari kerja dapat dilihat pada tabel 2 .

Tabel 2 Kendaraan Yang Melintas di Hari Kerja

\begin{tabular}{cccccccccc}
\hline No. & Waktu (WIB) & \multicolumn{7}{c}{ Sepeda Motor (unit) } \\
\cline { 3 - 10 } & & Titik 1 & Titik 2 & Titik 3 & Titik 4 & Titik 5 & Titik 6 & Titik 7 & Titik 8 \\
\hline $\mathbf{1}$ & $06.00-07.00$ & 189 & 191 & 72 & 135 & 54 & 122 & 124 & 55 \\
$\mathbf{2}$ & $07.00-08.00$ & 158 & 134 & 73 & 122 & 40 & 116 & 121 & 30 \\
$\mathbf{3}$ & $11.00-12.00$ & 108 & 92 & 75 & 116 & 92 & 120 & 111 & 41 \\
$\mathbf{4}$ & $12.00-13.00$ & 117 & 110 & 89 & 107 & 75 & 125 & 99 & 31 \\
$\mathbf{5}$ & $15.00-16.00$ & 149 & 120 & 89 & 113 & 131 & 141 & 96 & 35 \\
$\mathbf{6}$ & $16.00-17.00$ & 169 & 133 & 86 & $\mathbf{7 2}$ & 154 & 143 & 99 & 33 \\
\hline & Total & 890 & 780 & 484 & 665 & 546 & 767 & 650 & $\mathbf{2 2 5}$ \\
\hline No. & Waktu (WIB) & & & & Mobil (Unit) & & & \\
\hline $\mathbf{1}$ & $\mathbf{0 6 . 0 0 - 0 7 . 0 0}$ & $\mathbf{1 7}$ & $\mathbf{1 3}$ & $\mathbf{1 2}$ & $\mathbf{6}$ & $\mathbf{2 0}$ & $\mathbf{1 3}$ & $\mathbf{6}$ & $\mathbf{1}$ \\
$\mathbf{2}$ & $\mathbf{0 7 . 0 0 - \mathbf { 0 8 . 0 0 }}$ & $\mathbf{1 2}$ & $\mathbf{1 3}$ & $\mathbf{1 3}$ & $\mathbf{6}$ & $\mathbf{2 0}$ & $\mathbf{1 2}$ & $\mathbf{5}$ & $\mathbf{1}$ \\
$\mathbf{3}$ & $\mathbf{1 1 . 0 0 - 1 2 . 0 0}$ & $\mathbf{1 2}$ & $\mathbf{1 5}$ & $\mathbf{1 5}$ & $\mathbf{6}$ & $\mathbf{2 4}$ & $\mathbf{1 1}$ & $\mathbf{5}$ & $\mathbf{2}$ \\
$\mathbf{4}$ & $\mathbf{1 2 . 0 0 - 1 3 . 0 0}$ & $\mathbf{1 1}$ & $\mathbf{1 4}$ & $\mathbf{1 6}$ & $\mathbf{5}$ & $\mathbf{2 7}$ & $\mathbf{8}$ & $\mathbf{6}$ & $\mathbf{1}$ \\
$\mathbf{5}$ & $\mathbf{1 5 . 0 0 - 1 6 . 0 0}$ & $\mathbf{1 4}$ & $\mathbf{1 6}$ & $\mathbf{1 6}$ & $\mathbf{6}$ & $\mathbf{1 3}$ & $\mathbf{9}$ & $\mathbf{4}$ & $\mathbf{1}$ \\
$\mathbf{6}$ & $\mathbf{1 6 . 0 0 - 1 7 . 0 0}$ & $\mathbf{1 9}$ & $\mathbf{1 8}$ & $\mathbf{1 5}$ & $\mathbf{6}$ & $\mathbf{1 4}$ & $\mathbf{1 1}$ & $\mathbf{5}$ & $\mathbf{1}$ \\
\hline & Total & $\mathbf{6 5}$ & $\mathbf{8 9}$ & $\mathbf{8 7}$ & $\mathbf{3 3}$ & $\mathbf{1 1 8}$ & $\mathbf{6 4}$ & $\mathbf{3 1}$ & $\mathbf{7}$ \\
\hline
\end{tabular}

Sumber: Hasil Analisis, 2016

Pengukuran tingkat kebisingan dilakukan di sepanjang Jl. Sungai Raya Dalam di Daerah pemukiman bagian Kecamatan Pontianak Tenggara dengan menggunakan alat ukur Sound Level Meter. Dengan 
panjang 4,2 km dan pengukuran dilakukan setiap jarak $0,5 \mathrm{~km}$ sehingga didapatlah 8 titik pengambilan sampel yang dapat dilihat pada gambar 1. Pengambilan sampel dilakukan selama dua hari, yakni pada hari libur dan hari kerja guna untuk melihat perbandingan tingkat kebisingan untuk pengukuran di depan komplek perumahan yang ada di Jl. Sungai Raya Dalam Kecamatan Pontianak Tenggara dan dapat dilihat pada tabel 3 dan 4.

Tabel 3 Tingkat Kebisingan Pada Hari Libur

\begin{tabular}{cccc}
\hline Titik & \multicolumn{3}{c}{ Tingkat Kebisingan (dB) } \\
\cline { 2 - 4 } Sampling & $06.00-08.00$ & $11.00-13.00$ & $15.00-17.00$ \\
& WIB & WIB & WIB \\
\hline 1 & 61,3 & 62,9 & 64,2 \\
2 & 61,7 & 60,1 & 57,8 \\
3 & 58,7 & 61,3 & 64,4 \\
4 & 59,7 & 61,9 & 65,8 \\
5 & 59,9 & 57,9 & 64,7 \\
6 & 58,6 & 59,7 & 59,7 \\
7 & 58,3 & 59,7 & 60,1 \\
8 & 58,1 & 53,7 & 57,0 \\
\hline Sumber: Hasil Analisis, 2016 & \multicolumn{3}{c}{} \\
\multicolumn{4}{c}{ Tabel 4 Tingkat Kebisingan Pada Hari Kerja } \\
\hline Titik & \multicolumn{3}{c}{ Tingkat Kebisingan (dB) } \\
Sampling & $06.00-08.00$ & $11.00-13.00$ & $15.00-17.00$ \\
\multicolumn{4}{c}{ WIB } \\
\hline
\end{tabular}

Sumber: Hasil Analisis, 2016

Menurut Kementerian Lingkungan Hidup No. 48 tahun 1996 menyatakan bahwa ambang batas baku mutu untuk kebisingan di pemukiman tidak boleh melewati $55 \mathrm{~dB}(\mathrm{~A})$. Berdasarkan tabel 4.3 dan 4.4 menunjukkan bahwa tingkat kebisingan pada hari kerja melebihi ambang baku mutu untuk semua titik, sedangkan pada hari libur pada titik 8 masih dibawah ambang baku mutu, yakni sebesar 53,7 dB pada pukul 11.00 - 13.00 WIB. Hal ini dikarenakan kondisi eksisting di titik 8 masih terdapat banyak vegetasi. Titik 1 hingga 5 mengalami pembangunan infastruktur pesat sehingga banyak perkerasan dan mengakibatkan vegetasi berkurang sehingga tingkat kebisingan meningkat. Tetapi pada titik 6 hingga 8 masih terdapat banyak vegetasi. Menurut penelitian Hidayati (2007) menyatakan kawasan yang memiliki tanaman (rerumputan) dan ketinggian pagar dapat berfungsi sebagai pemantul dan penyerap bunyi yang diakibatkan oleh arus lalu lintas.

Tingkat kebisingan yang di tunjukan pada tabel 4 pada hari kerja meningkat dibandingkan dengan hari libur hal ini dapat dikaitkan dengan jumlah kendaraan yang lebih banyak melintas. Pada saat hari kerja, tingkat kebisingan tetinggi didominasi oleh titik satu dan pada tabel jumlah kendaraan titik satu merupakan titik yang paling besar jumlah kendaraan yang melintas, sehingga tingkat kebisingan semakin meningkat dan untuk tingkat kebisingan, nilai minimum ada pada titik 8 dan jumlah kendaraan yang melintas pada titik delapan berbanding lurus dengan intensitas kebisingan, sehingga dapat ditarik kesimpulan bahwa semakin tinggi jumlah kendaraan bermotor berpengaruh pada tingkat intensitas bising atau dapat dikatakan berbanding lurus antara jumlah kendaraan dengan tingkat kebisingan (Triwinarti, 2015). 


\section{B. Hasil Pengolahan Kuesioner}

Penyebaran kuesioner dilakukan dengan mengambil sampel sebanyak 120 responden yang dibagi dengan 8 kelompok hunian warga, dimana masing-masing kelompok diberi 15 buah kuesioner. Dasar pengambilan 120 sampel responden menurut Roscoe (1975) yang dikutip Sakran (2006) menyatakan bahwa penelitian korelasional jumlah sampel untuk menghasilkan hasil yang baik adalah 30 - 500 sampel. Responden berasal dari warga yang tinggal di Jl. Sungai Raya Dalam Kecamatan Pontianak Tenggara yang berada pada 8 titik pengambilan sampel dengan jumlah 8 komplek perumahan. Hasil kuesioner akan ditampilkan dalam diagram.

\section{Demografi Penduduk}

Untuk pertanyaan demografi berdasarkan tingkat pendidikan terakhir dapat dilihat pada gambar 4.

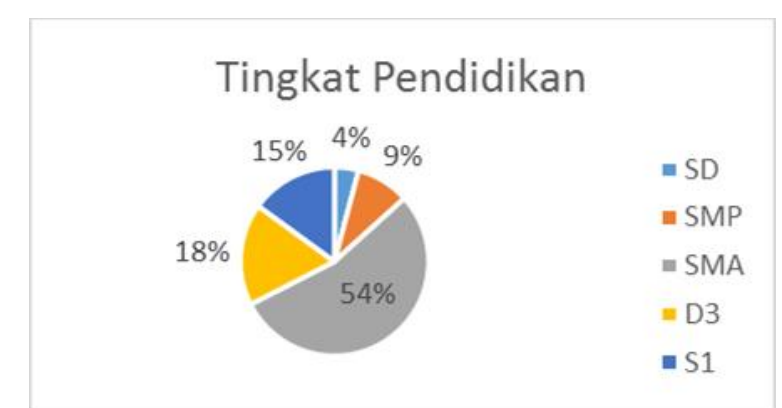

\section{Gambar 4 Berdasarkan Tingkat Pendidikan Terakhir}

Gambar 4 memperlihatkan hasil berdasarkan tingkat pendidikan terakhir dari 120 responden. Dapat dilihat pada gambar diagram bahwa sebagian besar penduduk di pemukiman Jl. Sungai Raya Dalam Kecamatan Pontianak Tenggara berpendidikan terakhir SMA dengan presentase sebesar 54\%, 18\% berpendidikan D3, 15\% S1, 9\% SMP dan 4\% berpendidikan terakhir SD. Hasil pengelolaan kuesioner berdasarkan lama waktu tinggal dapat dilihat pada gambar 5 .

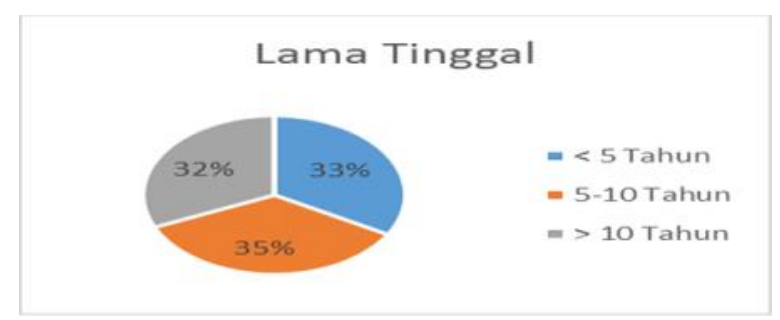

\section{Gambar 5 Hasil Berdasarkan Lama Tinggal}

Gambar 5 merupakan hasil dari berdasarkan waktu tinggal. Dapat dilihat pada diagram diatas bahwa sebanyak 35\% penduduk di pemukiman Jl. Sungai Raya Dalam Kecamatan Pontianak Tenggara tinggal dalam kurun waktu 5-10 tahun dan sebesar 32\% warga tinggal lebih dari 10 tahun.

\section{Skoring Kuesioner Dengan Skala Likert}

Skala Likert merupakan salah satu teknik self report untuk pengukuran sikap dimana subjek diminta memilih salah satu kata sifat atau frase dari sekelompok pasangan. Kata sifat atau pasangan frase yang disediakan adalah yang paling mampu menggambarkan perasaan mereka terhadap suatu objek. Dalam hal ini menggunakan persoalan pengukuran sikap terhadap tingkat kebisingan di pemukiman JI. Sungai Raya Dalam Kecamatan Pontianak Tenggara. Dalam pembuatan skala likert, pernyataan yang dibuat berhubungan dengan suatu isu atau objek, lalu subjek atau responden diminta untuk mengindikasikan tingkat ketergangguan atau ketidaktergangguan mereka terhadap pertanyaan. Hasil tersebut kemudian diolah menggunakan metode skala Likert. Skala Likert merupakan alat untuk mengukur (mengumpulkan data dengan cara mengukur/memberi skor yang pernyataannya berisikan (memuat) pilihan yang berjenjang) (Amirin, 2010). Dari hasil skala likert nilai tingkat ketergangguan masyarakat di pemukiman Jl. Sungai Raya Dalam mencapai 51\% termasuk dalam skala tingkat "Sedang Terganggu". 
Dari hasil perhitungan untuk tingkat ketergangguan yang dirasakan responden dimana aktivitas lalu lintas di Jl. Sungai Raya Dalam Kecamatan Pontianak Tenggara sudah mengganggu masyarakat yang bermukim di daerah tersebut. Dengan melihat jumlah kendaraan yang melintas dan tingkat kebisingan yang dialami sudah melewati batas baku mutu yang telah diputuskan oleh Kep. Menterian Lingkungan Hidup No. 48 pada tahun 1996, dimana batas kebisingan untuk daerah pemukiman tidak boleh melewati $55 \mathrm{~dB}(\mathrm{~A})$. Tetapi, beberapa warga yang tinggal di daerah tersebut menganggap bahwa tingkat kebisingan di daerah pemukiman tidak begitu mengganggu, hal ini dikarenakan oleh beberapa faktor seperti lamanya waktu tinggal yang menyebabkan beberapa responden merasa terbiasa dengan adanya bising dan bentuk bangunan yang dapat memantulkan bunyi. Melihat kondisi tempat pengambilan sampel yang sudah dipenuhi dengan ruko atau gedunggedung tinggi di depan pemukiman menjadi salah satu faktor yang menyebabkan kebisingan tidak begitu mengganggu. Tingkat kebisingan juga semakin rendah karena dipengaruhi oleh jarak dan adanya ruko yang berada di sepanjang jalan sehingga menyebabkan adanya reduksi tingkat kebisingan dari jalan raya ke perumahan. Beberapa faktor yang mempengaruhi tingkat kebisingan yaitu, jumlah kendaraan, jarak dan adanya bangunan sebagai barrier. Menurut penelitian Septiana (2015) menyatakan bahwa ketebalan dinding ruko juga mempunyai pengaruh dalam mereduksi kebisingan. Tingginya nilai penyerapan bunyi oleh bangunan ruko ini disebabkan karena adanya material bangunan bata memiliki pori-pori relatif kecil, sehingga sebagian besar gelombang bunyi yang datang diserap oleh material bangunan tersebut.

\section{Analisis Hubungan Kebisingan dan Tingkat Ketergangguan}

Responden yang dipilih berjumlah 120 dan merupakan warga yang tinggal di Jl. Sungai Raya Dalam Kecamatan Pontianak Tenggara sebagai daerah yang terpapar kebisingan. Dengan menggunakan 5 skala verbal dari hasil perhitungan menggunakan skala Likert menyatakan bahwa penduduk di Jl. Sungai Raya Dalam sudah merasa terganggu ditingkat sedang akibat kebisingan arus lalu lintas pada daerah tersebut. Pemukiman di Jl. Sungai Raya Dalam Kecamatan Pontianak Tenggara sudah memasuki daerah moderat bising, yakni berjarak $11 \mathrm{~s} / \mathrm{d} 20 \mathrm{~m}$ dari tepi perkerasan jalan. Nilai tingkat ketergangguan yang dirasakan masyarakat dapat dilihat pada tabel 5 .

Uji asosiasi yang dilakukan bertujuan untuk mengetahui hubungan di antara variabelvariabel terdapat hubungan yang signifikan atau tidak. Alat uji asosiasi meliputi korelasi dengan alat bantu aplikasi SPSS versi 16.0.

Tabel 5 Korelasi Tingkat Kebisingan Pada Hari Kerja

\begin{tabular}{|c|c|c|c|c|c|c|}
\hline & ariabel & $\begin{array}{c}\text { Ting. } \\
\text { Ketergangguan }\end{array}$ & $\begin{array}{c}\text { HK_Kebisingan } \\
\text { Pagi }\end{array}$ & $\begin{array}{c}\text { HK_Kebisingan } \\
\text { Siang }\end{array}$ & $\begin{array}{c}\text { HK_Kebisingan } \\
\text { Sore }\end{array}$ & Jarak \\
\hline Ting. & Pearson Correlation & 1 & .145 & .068 & .073 & .063 \\
\hline \multirow[t]{2}{*}{ Ketergangguan } & Sig. (2-tailed) & & .115 & .461 & .427 & .495 \\
\hline & $\mathrm{N}$ & 120 & 120 & 120 & 120 & 120 \\
\hline HK_Kebisingan & Pearson Correlation & .145 & 1 & $.928 * *$ & $.644^{* *}$ & $-.707^{* *}$ \\
\hline \multirow[t]{2}{*}{ Pagi } & Sig. (2-tailed) & .115 & & .000 & .000 & .000 \\
\hline & $\mathrm{N}$ & 120 & 120 & 120 & 120 & 120 \\
\hline HK_Kebisingan & Pearson Correlation & .068 & $.928 * *$ & 1 & $.547 * *$ & $-.686 * *$ \\
\hline \multirow[t]{2}{*}{ Siang } & Sig. (2-tailed) & .461 & .000 & & .000 & .000 \\
\hline & $\mathrm{N}$ & 120 & 120 & 120 & 120 & 120 \\
\hline HK_Kebisingan & Pearson Correlation & .073 & $.644 * *$ & $.574^{* *}$ & 1 & $-.281 * *$ \\
\hline \multirow[t]{2}{*}{ Sore } & Sig. (2-tailed) & .427 & .000 & .000 & & .002 \\
\hline & $\mathrm{N}$ & 120 & 120 & 120 & 120 & 120 \\
\hline \multirow[t]{3}{*}{ Jarak } & Pearson Correlation & .063 & $-.707 * *$ & $-.686 * *$ & $-.281 * *$ & 1 \\
\hline & Sig. (2-tailed) & .495 & .000 & .000 & .002 & \\
\hline & $\mathrm{N}$ & 120 & 120 & 120 & 120 & 120 \\
\hline
\end{tabular}

**. Correlation is signigicant at the 0,01 level (2-tailed)

Sumber: Hasil Analisis, 2016 
Tabel 6 Korelasi Tingkat Kebisingan Pada Hari Libur

\begin{tabular}{|c|c|c|c|c|c|c|}
\hline \multicolumn{2}{|c|}{ Variabel } & $\begin{array}{c}\text { Ting. } \\
\text { Ketergangguan } \\
1\end{array}$ & $\begin{array}{r}\text { HL_Kebisingan Pagi } \\
.024\end{array}$ & $\begin{array}{l}\text { HL_Kebisingan } \\
\text { Siang } \\
.024\end{array}$ & $\begin{array}{r}\begin{array}{l}\text { HL_Kebisingan } \\
\text { Sore }\end{array} \\
077\end{array}$ & $\begin{array}{r}\text { Jarak } \\
.063\end{array}$ \\
\hline Ketergangguan & Sig. (2-tailed) & & .799 & .793 & .941 & .495 \\
\hline HK_Kebisingan & Pearson Correlation & .024 & 1 & $.806^{* *}$ & $.678 * *$ & $-.777^{* *}$ \\
\hline \multirow[t]{2}{*}{ Pagi } & Sig. (2-tailed) & .799 & & .000 & .000 & .000 \\
\hline & $\mathrm{N}$ & 120 & 120 & 120 & 120 & 120 \\
\hline Siang & $\mathrm{N}$ & 120 & 120 & 120 & 120 & 120 \\
\hline HK_Kebisingan & Pearson Correlation & .077 & $.678^{* *}$ & $.727^{* *}$ & 1 & $-.646 * *$ \\
\hline \multirow[t]{2}{*}{ Sore } & Sig. (2-tailed) & .941 & .000 & .000 & & .000 \\
\hline & $\mathrm{N}$ & 120 & 120 & 120 & 120 & 120 \\
\hline \multirow[t]{2}{*}{ Jarak } & Pearson Correlation & .063 & $-.777^{* *}$ & $-.698 * *$ & -.646 & 1 \\
\hline & Sig. (2-tailed) & .495 & .000 & .000 & .000 & \\
\hline
\end{tabular}

**. Correlation is signigicant at the 0,01 level (2-tailed)

Sumber: Hasil Analisis, 2016

Tabel 5 dan 6 menyatakan bahwa adanya nilai hubungan antara tingkat kebisingan dengan tingkat ketergangguan dengan nilai 0,14, 0,06 dan 0,07 pada Tabel 5 dan nilai 0,02, 0,02, dan 0,07 pada Tabel 6 yang menyatakan bahwa tingkat ketergangguan berbanding lurus dengan tingkat kebisingan pada hari libur. Tetapi, menurut Singgih (2009) tidak ada ketentuan yang tepat mengenai apakah nilai korelasi tertentu menunjukkan tingkat korelasi yang tinggi atau lemah. Korelasi berbanding lurus antara tingkat kebisingan dan tingkat ketergangguan namun memiliki pengaruh yang kecil. Bangun (2009) menyatakan meskipun tingkat bising yang diterima masyarakat cukup tinggi, namun beberapa penduduk tidak lagi terganggu karena mereka sudah terbiasa terpapar oleh kebisingan.

Tabel 5 dan 6 juga menunjukkan hubungan antara jarak rumah dari jalan raya dengan tingkat kebisingan dan tingkat ketergangguan. Dapat dilihat bahwa nilai korelasi untuk jarak rumah dengan tingkat ketergangguan bernilai positif, yang berarti semakin dekat jarak rumah penduduk dengan jalan raya maka semakin tinggi pula tingkat ketergangguan. Dan untuk nilai antara tingkat kebisingan dengan jarak berbanding terbalik. Menurut Hasan (2004) jika koefisien korelasi bernilai negatif, maka variabel-variabel bernilai negatif. Dimana, apabila jarak rumah dengan jalan raya semakin besar maka tingkat kebisingan semakin kecil dan sebaliknya.

\section{Upaya Pengendalian Kebisingan}

Pengendalian kebisingan secara umum harus merujuk pada penataan bunyi yang menurut Satwiko (2004) akan melibatkan empat elemen, yaitu sumber suara, media, penerimaan bunyi dan gelombang bunyi. Pengurangan kebisingan menurut Egan, M.D, (1998), pengurangan kebisingan dapat dilakukan pada tiga aspek, yaitu pada sumber, media dan penerima. Ada beberapa cara pengendalian kebisingan, yaitu dengan mengurangi vibrasi sumber kebisingan berarti mengurangi tingkat kebisingan yang dikeluarkan sumbernya. Dengan aspek media menutupi sumber suaranya, melemahkan kebisingan dengan bahan penyerap suara atau peredam suara dan dengan aspek penerima menghalangi merambatnya suara, melindungi ruang tempat manusia atau makhluk lain yang menerima suara dan melindungi telinga dari suara. Menurut Zikri (2015) mengatakan upaya mengatasi kebisingan dapat berupa: Penanggulangan kebisingan langsung ke sumber bising, penanggulangan dapat dilakukan di bangunan, yaitu dengan membuat barrier dalam bentuk pagar atau dinding yang lebih tinggi sehingga kebisingan dapat bertahan dan dipantulkan. Penanggulangan dengan menggunakan jalur hijau, yaitu dengan menanam pohon di sekitar area pemukiman. Pohon dapat meredam suara dengan cara mengabsorpsi gelombang suara oleh daun, cabang dan ranting. Jenis tumbuhan yang paling efektif untuk meredam suara adalah yang mempunyai tajuk tebal dengan daun yang rindang. Dedaunan tanaman dapat menyerap kebisingan sampai 95\%. Dengan menanam berbagai jenis tanaman dengan berbagai strata yang terdiri dari pohon dan semak atau 
perdu yang cukup rapat dan tinggi akan dapat mengurangi kebisingan. Pedoman Kontruksi dan Bangunan Dinas Pekerjaan Umum tahun 2005.

\section{KESIMPULAN}

Kesimpulan yang dapat diambil dari pemaparan pembahasan adalah:

1. Tingkat kebisingan di pemukiman Jl. Sungai Raya Dalam Kecamatan Pontianak Tenggara sudah melebihi ambang baku mutu menurut Peraturan Kementrian Lingkungan Hidup No. 48 tahun 1996 yang hanya diperbolehkan sebesar 55 dB. Tingkat kebisingan tertinggi pada hari kerja berada pada titik satu, yakni pada komplek Villa Lestari dengan nilai sebesar 68,8 dB dan hari libur dengan nilai sebesar $65,8 \mathrm{~dB}$ pada pengukuran pukul $06.00-08.00$ WIB dan $15.00-17.00$ WIB.

2. Tingkat ketergangguan masyarakat di pemukiman Jl. Sungai Raya Dalam Kecamatan Pontianak tenggara akibat kebisingan yang bersumber dari arus lalu lintas sudah di tahap sedang terganggu dengan nilai sebesar $51 \%$ persen dari perhitungan skala Likert.

\section{UCAPAN TERIMA KASIH}

Dengan selesainya penelitian ini saya mengucapkan syukur kepada Allah SWT, terima kasih kepada kedua orang tua, kedua dosen pembimbing yaitu Bapak Kiki Prio Utomo, S.T, M.Sc dan Ibu Dian Rahayu Jati, S.T, M.Si serta teman-teman Prodi Teknik Lingkungan Angkatan 2011 yang telah banyak membantu penelitian ini. Harapan saya penelitian ini dapat bermanfaat bagi semua dan dapat dipergunakan sebagaimana mestinya.

\section{DAFTAR PUSTAKA}

Amirin, M.T. 2010. Skala Likert : Penggunaan dan Analisis Datanya. http://tatangmanguny.wordpress.com/. Diakses tanggal 1 April 2016.

Ansusanto, J.D. 2006. Prediksi Tingkat Kebisingan Kendaraan Bermotor Akibat Pertumbuhan Lalu Lintas. Universitas Atma jaya. Yogyakarta.

Badan Pusat Statistik Kalimantan Barat. 2015. Kalimantan Barat Dalam Angka. Pontianak.

Bangun, L.P. 2009. Kebisingan Lalu Lintas Dan Hubungannya Dengan Tingkat Ketergangguan Masyarakat (Studi Kasus: Jalan Bojongsoang, Kabupaten Bandung). Institut Teknologi Bandung. Bandung.

Departemen Kesehatan RI. 1996. Parameter Pencemaran Udara dan Dampaknya Terhadap Kesehatan Sub Proyek Analisis Dampak Kesehatan Lingkungan. Jakarta.

Dinas Pendapatan Kalimantan Barat. 2011. Pertumbuhan Kendaraan Bermotor di Kalimantan Barat. Pontianak.

Dinas Perhubungan RI. 2011. Pertumbuhan Pertambahan Jumlah Kendaraan. Jakarta.

Hasan, Misbahhudin Iqbal. 2004. Analisis Data Penelitian Dengan Statistik. Bumi Askara: Jakarta.

Hidayati, N. 2007. Pengaruh Arus Lalu Lintas Terhadap Kebisingan (Studi Kasus: Beberapa Zona Pendidikan di Surakarta).

Keputusan Direktur Jendral Bina Marga. 1999. Pedoman Perencanaan Teknik Bangunan Peredam Bising.

Sakran, Uma. 2006. Metodologi Penelitian Untuk Bisnis. Jakarta.

Satwiko, P. 2004. Fisika Bangunan 1. Andi. Jakarta.

Septiana, S. 2015. Analisa Pengaruh Keberadaanan Terhadap Tingkat Kebisingan di Sepanjang Jalan Raya. Pekan Baru-Bangkinang. Universitas Riau. Riau.

Singgih, Santoso. 2009. Panduan Lengkap Menguasai Statistik Dengan SPSS. Jakarta.

Triwinarti, T. 2015. Studi Kebisingan Lalu Lintas di Kawasan Universitas Brawijaya Malang. Universitas Brawija. Malang.

Zikri, Moehammad Ryan. 2015. Analisis Dampak Kebisingan Terhadap Komunikasi dan Konsentrasi Belajar Siswa Sekolah Pada Jalan Padat Lalu Lintas. Universitas Tanjungpura. Pontianak 